\title{
Off-Label Prescribing in Pediatric Inpatients with Pneumonia in a Children's Hospital
}

\section{Peresepan Off-Label pada Pasien Pediatrik Rawat Inap dengan Peneumonia di Sebuah Rumah Sakit Anak}

\author{
Hesty Utami Ramadaniati ${ }^{1 *}$, Heni Safarini ${ }^{2}$, Aishah A Regine ${ }^{1}$ \\ ${ }^{1}$ Department of Clinical and Community Pharmacy, Faculty of Pharmacy \\ Pancasila University, Jakarta, 12640. \\ 2Department of Pharmacy, Harapan Kita Mother' and Children's Hospital, \\ Jakarta,11420.
}

\begin{abstract}
Submitted 20 December 2017, Accepted 5 February 2018
Abstract: Off-label is a term used in which a drug prescribed outside the official information of the marketing authorization. Off-label prescribing may occur as the result of several factors including lack of clinical trials data involving pediatrics and suitable formulations for medicines commonly prescribed to this fragile population. This study aimed to estimate the nature and prevalence of off-label prescribing in pediatric inpatients with pneumonia. A retrospective study was conducted in a study hospital using medical records from pediatric inpatients with pneumonia during the period of January-December 2015. Patient and prescribing data were collected, and drugs were classified as on-label or off-label based on the Indonesia National Drug Information (IONI) and British National Formulary for Children (BNFC). Thereafter, off-label drugs were categorized with a hierarchical system of age, indication, route of administration and dosage. There were 1141 drugs with 77 different types of drug were administered to 207 patient during the study period. The data uncovered that 405 (35.5\%) of the drug prescriptions were used off-label based on IONI, and 319 (28\%) of the drug were used off-label based on BNFC. Based on IONI and BNFC, most off-label drugs were from anti infection drugs. The prevalence of off-label use in pediatric inpatients with pneumonia is not high. The off-label prescribing may not be necessarily be considered irrational, yet this fact reveals that the use of drugs does not comply with the drug label. Clinical trials for pediatric drugs are essential to provide complete product information for pediatric use.
\end{abstract}

Keywords: Off-label drugs, pneumonia, pediatric, inpatients.

\begin{abstract}
Abstrak: Off-label adalah istilah yang digunakan untuk obat yang diresepkan di luar informasi resmi dari otorisasi pemasaran. Peresepan off-label dapat terjadi sebagai hasil dari beberapa faktor termasuk kurangnya data uji klinis yang melibatkan pediatri dan formulasi yang sesuai untuk obat-obatan yang biasa diresepkan untuk populasi yang rapuh ini. Penelitian ini bertujuan untuk memperkirakan sifat dan prevalensi resep off-label pada pasien rawat inap anak dengan pneumonia. Kajian retrospektif dilakukan di rumah sakit menggunakan rekam medis dari pasien rawat inap anak-anak dengan pneumonia selama periode Januari-Desember 2015. Data pasien dan resep dikumpulkan, dan obat-obatan diklasifikasikan sebagai label di atas atau di luar label berdasarkan pada Informasi Obat Nasional Indonesia (IONI) dan British National Formulary for Children (BNFC). Setelah itu, obat-obatan off-label dikategorikan dengan sistem hierarkis usia, indikasi, rute pemberian dan dosis. Ada 1141 obat dengan 77 jenis obat yang berbeda diberikan kepada 207 pasien selama masa studi. Data menemukan bahwa 405 (35,5\%) dari resep obat yang digunakan off-label berdasarkan IONI, dan $319(28 \%)$ dari obat itu digunakan off-label berdasarkan BNFC. Berdasarkan IONI dan BNFC, sebagian besar obat tidak diberi label berasal dari obat anti infeksi. Prevalensi penggunaan off-label pada pasien rawat inap anak dengan pneumonia tidak tinggi. Peresepan off-label mungkin tidak perlu dianggap tidak rasional, namun fakta ini menunjukkan bahwa penggunaan obat-obatan tidak sesuai dengan label obat. Uji klinis untuk obat anak sangat penting untuk menyediakan informasi produk lengkap untuk penggunaan pediatrik.
\end{abstract}

Kata kunci: Obat tanpa label, pneumonia, pediatri, pasien rawat inap.

\footnotetext{
* Correspondence Author, Hp. 081314099130

e-mail: h.ramadaniati@postgrad.curtin.edu.au
} 


\section{INTRODUCTION}

DRUG label is the official information of a drug product provided by a pharmaceutical company during registration process and approved by an authorized institution (e.g. National Agency of Food and Drug Control in Indonesia). In addition to other clinical evidence sources, drug label can be used by healthcare professionals to gather information during their practice. Prescribing practice corresponding with the product label has been considered as one of measures to support the rational use of medicine ${ }^{(1)}$.

The term "off-labels" refers to use of a drug that is not included in the product labeling for that drug (unapproved indication, unapproved age range, unapproved dosage, or unapproved route of administration) $)^{(2)}$. It is of importance to note that the absence of labeling in pediatric patients does not necessarily imply that the use of the medicine is inappropriate and unsupported by evidence. Rather, it possibly points out that evidence for drug safety and efficacy in the pediatric population has not been submitted for review or has not met the regulatory standards of "substantial evidence" for approval by the authorized institution ${ }^{(2)}$. Off-label prescribing in children mainly occur as the result of several factors including lack of clinical trials data involving pediatrics and suitable formulations for medicines commonly prescribed to this fragile population ${ }^{(3)}$.

It has been evident that the studies of off-label prescribing in pediatrics have been conducted in a range of settings. Nevertheless, it is intriguing to note that the information regarding the use of offlabel drugs in children diagnosed with pneumonia is still lacking in Indonesia. Pneumonia itself is defined as a condition typically associated with fever, respiratory symptoms and evidence of parenchymal involvement. The World Health Organization (WHO) estimates there are 156 million cases of pneumonia in children especially those younger than five years, with as many as 20 million cases severe enough to require hospital admission ${ }^{(4)}$. Further, pneumonia has been reported as one of major causes of childhood mortality in developing countries worldwide including Indonesia ${ }^{(5)}$. Thus, this study aimed to estimate the nature and prevalence of off-label prescribing in pediatric inpatients with pneumonia.

\section{MATERIAL AND METHODS}

A retrospective study was conducted in general pediatric wards in a major mother' and children's hospital in Indonesia during the period of JanuaryDecember 2015. There were approximately 160 hospital admissions each day to the hospital during the study period. The data were collected from medical records of pediatric patients hospitalized due to pneumonia to pediatric wards during the study period. Patients with incomplete data were excluded. The sample size was determined using the Krejcie Morgan table. The data collected included patient characteristics (date of birth, sex, weight, height, past medical history, diagnosis, length of stay, number of medications prescribed during hospitalization) and prescribing details (date of prescription data, dose, dosage form, strength of drug, dosing frequency/ interval). The patient's age was classified according to the European Medicines Agency age classification: newborns (0-27 days), infants and toddlers (28 days23 months), children (2-11 years) and adolescents $(12-18 \text { years })^{(6)}$.

Drugs were classified as on-label or off-label/ unlicensed based on Indonesia National Drug Information/IONI $2015^{(7)}$ and British National Formulary for Children/BNFC ${ }^{(8)}$. Off-label drugs were categorized with a hierarchical system established by Hsien $e t a l^{(9)}$. Categories of off-label were defined as follows:

* Age/weight: administration of a prescribed drug outside the age range or weight for which the product is licensed.

* Indication: prescribed for indication not mentioned in the Product Label.

* Route of administration: the use of alternative routes of administration other than the approved route for that formulation in the Product Label.

* Dosage (including dose, frequency): the use of doses or dose frequencies not stated in the approved Product Label.

A drug was considered off-label if met at least one of the above criteria according to IONI 2015 or BNFC. A sequential approach was used for this study in which all prescription drugs were initially analyzed for age. Drugs with no pediatric information or those prescribed for an age group for which the drug was not licensed were classified as off-label for age. The next level was indication, route of administration and dosage subsequently. Once drugs were classified into higher level (e.g. off-label category for age), those drugs were not analyzed for possible classification into any subsequent category ${ }^{(9)}$. Further, drugs were categorized unlicensed if they were unregistered drugs, unlicensed formulations of registered drugs or the use of non-pharmacological substances as medicines ${ }^{(1)}$. In case where a drug was classified both off-label and unlicensed, the final classification was off-label. The 
drugs were classified based on the WHO Anatomical Therapeutic Chemical (ATC) code. Prescriptions for parenteral nutrition, oxygen and investigational drugs were not included.

Patient and prescribing-related data were summarized using descriptive statistics (mean \pm standard deviation or median [range] for variables measured on a continuous scale, and frequencies and percentages for categorical variables). The study protocol was approved by Faculty of Pharmacy Pancasila University Institutional Review Board and Human Ethics Committee at the study hospital.

\section{RESULTS AND DISCUSSION}

There were 207 patients who met the inclusion criteria during the study period and the characteristics of patients and the diseases are detailed in Table 1. As presented in Table 1, patients ranged in age from newborns to 18 years with the majority of patients $(72.5 \%)$ aged less than 2 years old. Slightly more male patients $(57.5 \%)$ admitted to hospital due to pneumonia as opposed to their female counterparts. In addition, the data shows that the patients spent on average 5 days during their hospitalization and they were admitted only one time during the data collection period. The data also uncovered diarrhea, anemia, congenital heart disease as the commonest comorbidities amongst the patients.

A total of 1141 drugs consisting of 74 different drugs were prescribed in which each patient received approximately 6 drugs during hospital stay. Table 2 details the frequency of drugs in each ATC subcategory. It can be seen in Table 2 that anti-infectives for systemic use ( $\mathrm{n}=371,32.5 \%)$ constituted the most frequently prescribed drugs, followed by drug class for nutrition and blood $(b=295,25.9 \%)$.

Table 1. Patients' Demographic Characteristics and Data Related to Disease during The Study Period $(\mathrm{N}=207)$.

\begin{tabular}{ll}
\hline Patient characteristics & Value \\
\hline Age group (\%) & \\
Newborns (0-27 days) & $1(0.5)$ \\
Infants and toddlers (28 days 23 months) & $150(72.5)$ \\
Children (2-11 years) & $54(26.1)$ \\
Adolescents (12-18 years) & $2(0.9)$ \\
Gender (\%) & \\
Male & $119(57.5)$ \\
Female & $88(42.5)$ \\
Median length of stay in days & 5 \\
Median number of hospital admission & 1 \\
\hline
\end{tabular}

$\mathrm{N}=$ Number of patients who met the inclusion criteria (i.e. 207 patients)
Table 2. Frequency of All Drugs (On-label, Off-label) Based on Indonesia National Drug Information (IONI) and British National Formulary for children (BNFC)

\begin{tabular}{|c|c|c|c|c|}
\hline \multirow{2}{*}{$\begin{array}{l}\text { Drug Classification } \\
(\mathrm{N}=1141)\end{array}$} & \multicolumn{2}{|l|}{ IONI } & \multicolumn{2}{|l|}{ BNFC } \\
\hline & $\begin{array}{l}\text { On-label } \\
(\mathrm{N}=736, \\
64.5 \%)\end{array}$ & $\begin{array}{l}\text { Off-label } \\
(\mathrm{N}=405,35.5 \%)\end{array}$ & $\begin{array}{l}\text { On-label } \\
(\mathrm{N}=822,72.1 \%)\end{array}$ & $\begin{array}{l}\text { Off-label } \\
(\mathrm{N}=319 \text {, } \\
27.9 \%)\end{array}$ \\
\hline $\begin{array}{l}\text { Alimentary tract and } \\
\text { metabolism }(n=21,1.84 \% 0\end{array}$ & 7 & 14 & 13 & 8 \\
\hline $\begin{array}{l}\text { Cardiovascular system } \\
(\mathrm{n}=79,6.9 \%)\end{array}$ & 23 & 56 & 46 & 33 \\
\hline $\begin{array}{l}\text { Respiratory system }(\mathrm{n}=121 \text {, } \\
10.6 \%)\end{array}$ & 85 & 36 & 45 & 76 \\
\hline $\begin{array}{l}\text { Nervous system }(\mathrm{n}=121 \text {, } \\
106 \%)\end{array}$ & 87 & 34 & 104 & 17 \\
\hline $\begin{array}{l}\text { Anti-infectives }(n=371, \\
32.5 \%)\end{array}$ & 151 & 220 & 235 & 136 \\
\hline $\begin{array}{l}\text { Endocrine system }(\mathrm{n}=93, \\
8.2 \%)\end{array}$ & 50 & 43 & 47 & 46 \\
\hline $\begin{array}{l}\text { Nutrition and blood }(\mathrm{n}=295 \text {, } \\
25.9 \%)\end{array}$ & 231 & 64 & 231 & 64 \\
\hline Other $(n=40,3.5 \%)$ & 37 & 3 & 37 & 3 \\
\hline
\end{tabular}

When using IONI as the standard, our findings revealed that approximately $35 \%(n=405)$ of the drugs were used off-label, whilst lower proportion $(n=319,27.9 \%)$ was uncovered with BNFC as the standard. It can be inferred from the findings that generally each patient received approximately 2 offlabel drugs during their stay in the hospital. Despite slightly different proportion of off-label drugs between IONI and BNFC, anti-infectives for systemic use were reported as the most common drug class prescribed in off-label manner if assessed with any of the two standards. Further, the most frequent off-label drugs based on IONI and BNFC can be seen in Table 3. Intriguingly, there was a similar pattern shared by the two standards in which antibiotics predominated the most common off-label drugs. This fact was not surprising given the high use of this drug class. It has been evident that bacterial infections are responsible as one of major underlying causes of pneumonia in children and definitive information about the causative organism is usually unknown or may not be timely available. Hence, antibiotics, particularly

Table 3. The top five off-label drugs based on Indonesia National Drug Information/IONI and British National formulary for Children/BNFC.

\begin{tabular}{llll}
\hline \multicolumn{2}{ll}{ Off-label druggs based on I0NI (N=405) } & \multicolumn{3}{l}{ Off-label drugs based on BNFC (N=319) } \\
\hline Drugss & Frequency (\%) & Druggs & Frequency (\%) \\
\hline Ceftriaxone & $47(11.6)$ & Aminophyllin & $50(15.7)$ \\
Bactesyn & $44(10.9)$ & Ceftriaxone & $49(15.4)$ \\
Amilkacin & $39(9.6)$ & Dexamethasone & $40(12.5)$ \\
Dexamethasone & $28(6.9)$ & Cefotaxime & $20(6.3)$ \\
Cefotaxime & $23(5.7)$ & Meropenem & $19(5.9)$ \\
\hline
\end{tabular}

$\mathrm{N}=$ Number of off-label drugs 
for empirical use, play significant role in management of pneumonia ${ }^{(10)}$. A hierarchichal approach was used in assigning reasons for prescribing. Order of the hierarchy was age, indication, route of administration and dosage. Figure 1 and Figure 2 present the reasons for off-label prescribing based on IONI and BNFC, respectively. As shown in Figure 1, the high rate of offlabel drug use in children was mainly related to dosage $(n=231,757.6 \%)$ and age $(n=171,42.2 \%)$, whilst the least common reason for off-label prescribing was due to indication $(n=3,0.7 \%)$. Further, this study did not find route of administration as the reason for off-label use. A similar pattern of reasons to prescribe off-label drugs was observed when using BNFC as the standard (see Figure 2) although the rate of off-label drugs due to dosage was considerably high $(\mathrm{n}=280,87.7 \%)$.

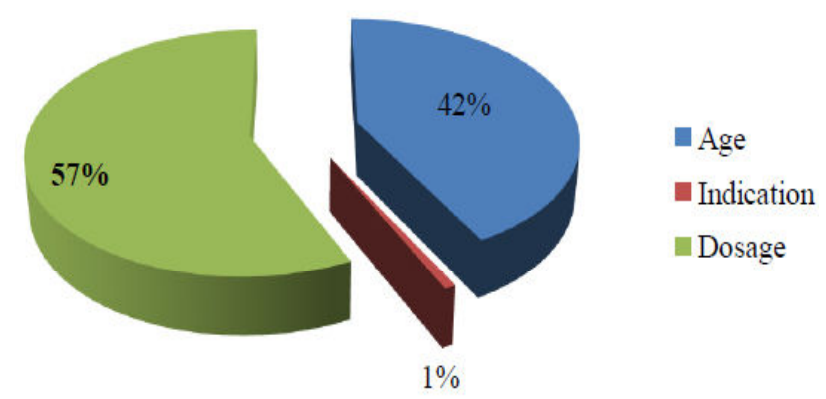

Figure 1. Reasons for Off-Label Prescribing Based on Indonesia National Drug Information.

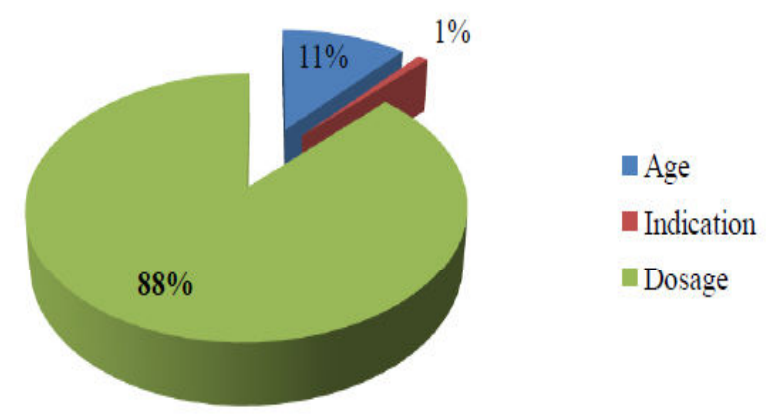

Figure 2. Reasons for off-label prescribing based on British National Formulary for Children

To the best of our knowledge, this is the first study in Indonesia on the prevalence of off-label in pediatric inpatients pneumonia from a major hospital. Our study found the proportion of off-label based on IONI and BNFC were $35.5 \%$ and $27.9 \%$, respectively. The proportion of off-label drugs based on BNFC was lower than IONI presumably due to the specialty context of BNFC as the pediatric prescribing reference compared to IONI being the general drug information. It has been evident that the majority of off-label studies have been conducted on patients with varied reasons for admission. Little study has been done to specifically focus on patients admitted due to pneumonia as the major diagnosis. It is quite unfortunate that our findings cannot be compared with other off-label studies focusing on pneumonic pediatric patients. Nevertheless, when comparing the result with other general pediatric studies, the off-label percentage in the present study was quite similar to those documented in several overseas studies in the Switzerland $(25 \%)^{(11)}$, Malaysia $(34 \%)^{(12)}$, Netherlands, Sweden and Italy $(39 \%)^{(13)}$. However, in comparison to pediatric studies with specific medical condition (i.e. renal disease), the percentage of off-label drugs in this study was considerably lower than that of reported in France $(63 \%)^{(14)}$ and Israel $(55 \%)^{(15)}$. The varied prevalence of off-label prescribing reported in the present study and other pediatric studies was likely due to the variety of patients' medical conditions requiring different drugs and the different standards used for assigning on-label/off-label drugs.

It is important to note that off-label use of some drugs are not synonymous with inappropriate prescribing as their use is often clinically appropriate and justified by high-quality evidence ${ }^{(16)}$. The prescribing practice in the study hospital has complied with clinical pathway which has taken into account the recent evidence-based literatures either from local studies or international clinical studies. Therefore, off-label use of drugs in this case is mostly justified as the clinicians in the study hospital have considered the reliable evidence and their clinical judgment when prescribing the drugs in an off-label manner. Additionally, recently there is no regulation yet in Indonesia as to the use of medicines outside their labels. Nonetheless, it is judicious that clinicians should clearly inform the reasons for using the medicines in off-label manner along with the supporting evidence. Then, the reasons for off-label prescribing should be well-documented within patients' medical record and communicated to patients and/or their carers ${ }^{(16)}$.

It has been widely known that the main reasons for off-label prescribing are attributed to lack of quality clinical trials in children leading to inadequate pediatric labeling of drugs. In addition, the complex and lengthy revision process of previously approved drug information may worsen the situation resulting in extensive use of off-label drugs ${ }^{(17)}$. However, it is of importance to realize that the scientific literature is often available and adequately supports the off-label use of certain medicines. Therefore, some countries (e.g the Unites States and European countries) have introduced the new legislation to facilitate the provision of evidence-based drugs for pediatric patients. The 
legislation has encompassed many aspects including economic incentives for pharmaceutical industry to undertake clinical trials involving pediatric population, and pressure for national regulatory agencies and research organizations to ensure the performance of high ethical and scientific quality of pediatric clinical trials ${ }^{(18,19)}$. The legislation also focuses on the measure to simplify the procedures in updating the product information $^{(18,19)}$.

The present study has some limitations. Firstly, the hierarchical approach in classifying the off-label drugs suffered an issue where in some cases the proportion of drugs classified as off-label due to indication, route of administration or dose would have been higher if the approach had not been used. Secondly, this study was conducted in one hospital so the results should be interpreted cautiously. It is recommended that the future studies may be conducted in multiple institutions with similar patient characteristics so the nature and prevalence of off-label drugs in pediatric patients with pneumonia can be revealed more comprehensively. In addition, the findings may not be accurately compared with other off-label studies due to variations in settings, design, duration, size, method and operational definitions of off-label drugs.

\section{CONCLUSION}

The prevalence of off-label use in pediatric inpatients with pneumonia in this study is not high compared to other pediatric studies. The off-label prescribing may not be necessarily be considered irrational, yet this fact reveals that the use of drugs does not comply with the drug label. Clinical trials for pediatric drugs are essential to provide complete product information for pediatric use.

\section{REFERENCES}

1. Turner S, Longworth A, Nunn AJ, Choonara I. Unlicensed and off label drug use in paediatric wards: prospective study. British Medical Journal. 1998;316:343-5.

2. The American Academy of Pediatrics. Policy statement: off-label use of drugs in children. Pediatrics. 2014;133:563-7.

3. Sinha Y, Cranswick NE. How to use medicines in children: principles of paediatric clinical pharmacology. Journal of Paediatric and Childhood Health. 2007;43:107-11.

4. Rudan I, Boschi-Pinto C, Biloglav Z. Epidemiology and etiology of childhood pneumonia. Bulletion of World Health Organization. 2008;86:408.
5. Harris M, Clark J, Coote N. British Thoracic Society guidelines for the management of community acquired pneumonia in children: update 2011 . Thorax. 2011;66:ii1.

6. European Medicines Agency. ICH Topic E11 clinical investigation of medicinal products in the paediatric population 2001. Available from: http://www.ema. europa.edu/docs/en_GB/document_library/Scientific_ guideline/2009/09/WC500002926.pdf.

7. Badan Pengawasan Obat dan Makanan. Informatorium obat nasional Indonesia. Jakarta: Badan Pengawasan Obat dan Makanan; 2015.

8. The Paediatric Formulary Committee. British National Formulary for Children. London: Pharmaceutical Press; 2011.

9. Hsien L, Breddemann A, Frobel AK, Heusch A, Schmidt K. Off-label drug use among hospitalised children: identifying areas with the highest need for research. Pharmacy and World Science. 2008;30(5):497-502.

10. Margolis P, Gadomski A. The rational clinical examination: dose this infant have pneumonia?. Journal of American Medical Association. 1998;279:308-13.

11. Paolo ER, Stoetter H, Cotting J, Frey P, Gehri M, Beck-Popovic M. Unlicensed and off-label drug use in a Swiss paediatric university hospital. Swiss Medical Weekly. 2006;136(13):218-22.

12. Lee J, Redzuan A, Shah NM. Unlicensed and off-label use of medicines in children admitted to the intensive care units of a hospital in Malaysia. International Journal of Clinical Pharmacy. 2013;35(6):1025-9.

13. Conroy S, Choonara I, Impicciatore P, Mohn A, Arnell H, Rane A. Survey of unlicensed and off-label drug use in paediatric wards in European countries. British Medical Journal. 2000;320(7227):79-82.

14. Avenel S, Bomkratz A, Dassieu G, Janaud JC, Danan C. Incidence des prescriptions hors autorisation de mise sur le marche en reanimation neonatale. Archives de Pediatrie. 2000;7(2):143-7.

15. Barr J, Brenner-Zada G, Heiman E, Pareth G, Bulkowstein M, Greenberg R. Unlicensed and offlabel medication use in a neonatal intensive care unit: a prospective study. American Journal of Perinatology. 2002;19(2):67-72.

16. Hattingh L. Guidelines for off-label medicine use. Australian Pharmacist. 2014:70-1.

17. Kimland E, Odlind V. Off-label drug use in pediatric patients. Clinical Pharmacology and Therapeutics. 2012;91(5):796-801.

18. European Medicines Agency. Medicines for children 2006. Available from: http://www.ema. europa.eu/ema/index.jsp?curl=pages/regulation/ document_listing/document_listing_000068. jsp\&mid $=\bar{W} C 0 \mathrm{~b} 01 \mathrm{ac} 0580025 \mathrm{~b} 8 \overline{\mathrm{b}}$.

19. The United States Congress. Pediatric research equity act 2003; (S.650). Available from: http:/govtrack.us/ congress/bills/108/s650. 